\title{
The Ins and Outs of Chemokine-Mediated Immune Cell Trafficking in Skin Cancer
}

\author{
Andrew O. Yam ${ }^{1,2}$ and Tatyana Chtanova ${ }^{1,2 *}$ \\ ${ }^{1}$ Immunology Division, Garvan Institute of Medical Research, Sydney, NSW, Australia, ${ }^{2}$ Faculty of Medicine, St Vincent's \\ Clinical School, University of New South Wales, Sydney, NSW, Australia
}

Recent studies of the patterns of chemokine-mediated immune cell recruitment into solid tumors have enhanced our understanding of the role played by various immune cell subsets both in amplifying and inhibiting tumor cell growth and spread. Here we discuss how the chemokine/chemokine receptor networks bring together immune cells within the microenvironment of skin tumors, particularly melanomas, including their effect on disease progression, prognosis and therapeutic options.

Keywords: immune cell, chemokine, skin cancer, melanoma, migration

\section{OPEN ACCESS}

Edited by:

Elin Solomonovna Gray,

Edith Cowan University, Australia

Reviewed by:

Su Yin Lim,

Macquarie University, Australia Jordan Jacobelli,

National Jewish Health, United States

*Correspondence:

Tatyana Chtanova

t.chtanova@garvan.org.au

Specialty section:

This article was submitted to Cytokines and Soluble Mediators in

Immunity,

a section of the journal

Frontiers in Immunology

Received: 08 November 2018

Accepted: 14 February 2019

Published: 07 March 2019

Citation:

Yam AO and Chtanova T (2019) The Ins and Outs of Chemokine-Mediated Immune Cell Trafficking in Skin Cancer.

Front. Immunol. 10:386

doi: 10.3389/fimmu.2019.00386

\section{INTRODUCTION}

Chemokines and their receptors are an intrinsic part of immune cell trafficking. They orchestrate cell-to-cell interactions during normal immune responses and are fundamental for directing immune cells to sites of inflammation (1). Chemokines are chemoattractant molecules $8-10 \mathrm{kDa}$ in size that can induce directed migration in nearby cells. They bind to G-protein coupled chemokine receptors and can be divided into four families based on the pattern of their cysteine residues: CC, CXC, CX3C, and C.

Chemokine receptor-ligand pairs play a key role in tumorigenesis in addition to infection and inflammation (2-4). Within the tumor microenvironment, both host and cancer cells can release a range of chemokines, leading to recruitment and activation of different immune cell subsets that can either enhance or inhibit anti-tumor immunity (5-9). These subsets include tumor infiltrating lymphocytes and cells of the innate immune system such as neutrophils, dendritic cells (DCs) and monocyte/macrophages.

Tumors can be broadly divided into $\mathrm{T}$ cell-inflamed and non-inflamed tumors (10). T cell-flamed tumors are characterized by type 1 interferon expression and chemokines that attract $\mathrm{T}$ cells and antigen presenting cells (10). T cell infiltration of tumors has been associated with improved survival and response to immunotherapy (11). However, in some cases infiltrating cytotoxic $\mathrm{T}$ cells can be functionally exhausted, whereas recruitment of regulatory $\mathrm{T}$ cells (Tregs) promotes tumor growth by suppressing anti-tumor responses (12). Innate immune cells including macrophages and neutrophils, which can have either pro- or anti-tumor functions, also contribute to the outcome of the tumor immune response (13-15). Thus, the potential exists to manipulate chemokine signaling in such a way as to enhance recruitment of cytotoxic cells into non-inflamed tumors or to shift the balance in inflamed tumors in favor of effector rather than regulatory cells.

In addition to their primary role as chemoattractants, chemokines are involved in other tumor-related processes and may be exploited by tumors to promote tumor cell growth (2), angiogenesis (16), and metastasis (17). A comprehensive discussion of the role of 
chemokines in cancer has been the subject of several recent reviews (18-20). Here we shall, therefore, focus on the part played by chemokines and their receptors in immune cell recruitment in skin cancers with specific emphasis on melanoma, since the vast majority of the available data on skin cancer comes from studies of patients with melanoma or murine models of melanoma.

\section{CHEMOKINE-DRIVEN INNATE IMMUNE CELL INFILTRATION IN SKIN CANCER}

Innate immune cells, among them DCs, macrophages, neutrophils and NK cells form an important part of the tumor immune milieu. Their role in skin cancers can be 2 -fold: either they can mediate direct anti-tumor toxicity through promoting cytotoxic $\mathrm{T}$ cell recruitment and activation or they can contribute to inhibition of anti-tumor responses through inhibitory interactions with other cells and secretion of suppressive molecules (Table 1).

\section{DCs}

DCs are not only the professional APC responsible for activating naïve $\mathrm{T}$ cells in secondary lymphoid tissue (45), but can also influence cytotoxic $\mathrm{T}$ cell recruitment into tumors. Thus, CXCL9/10, a chemokine associated with CD8+ T cell infiltration $(6,46)$, was produced by Batf3-driven CD103+ DCs present in the melanoma microenvironment (47). Consistent with an important role for CD103+ DCs in trafficking antigen and $\mathrm{T}$ cell activation in tumor draining lymph nodes (45), depletion or lack of this subset prevented intrinsic and adoptive $\mathrm{T}$ cell recruitment into tumors (47). However, since Tregs also express CXCR3, the receptor for CXCL9/10 (48), this may also promote recruitment of immunosuppressive cells. Expression of the DC chemoattractant CCL20 led to DC recruitment and $\mathrm{T}$ cell-dependent inhibition of B16 murine syngeneic melanoma (31). Similarly, the positive association of CXCL12 with cytotoxic $\mathrm{T}$ cell recruitment was related to the presence of DCs within melanoma. Transfection of CXCL12 into B16 melanoma cells induced DC accumulation within the tumor and reduced tumor growth in a CD8+ $\mathrm{T}$ celldependent manner (43). Likewise, recruitment of conventional DCs into melanoma by CCL5 and XCL1, whose production was dependent on NK cells, promoted tumor growth control (5). Supporting this data, the combination of NK and DC tumor gene signatures from The Cancer Genome Atlas correlated with melanoma patient survival (5), while NK cells in melanoma predicted response to anti-PD1 by regulating the DC abundance in tumors through secretion of cytokine FLT3LG (49).

\section{Macrophages}

Macrophages are also frequently found in solid tumors including melanomas where they may have dual roles leading to their classification into anti-tumor M1 and inhibitory M2 subtypes (14). M2 macrophages preferentially express proangiogenic factors and metalloproteinases, which contribute to a microenvironment conducive to tumor growth $(14,50)$. CCL20producing tumor associated macrophages were associated with tumor progression and worse survival possibly because they co-expressed pro-tumor cytokine TNF and pro-angiogenic VEGF-A (30).

The macrophage chemoattractant CCL2 is expressed on melanoma cells (22) and its effect on macrophage function in melanoma is concentration-dependent (23). Low levels of CCL2 led to modest macrophage infiltration and tumor formation by promoting angiogenesis, whilst higher levels were associated with increased macrophage infiltration and tumor regression. Furthermore, expression of CCL2 in human IIBMEL-J melanoma increased intra-tumor macrophage infiltration and tumor growth while macrophage-depleted mice developed smaller tumors (51). CCL2 macrophage recruitment into melanoma was associated with higher-grade melanoma (31) and promotion of tumor growth through increased TNF- $\alpha$ dependent vascularization $(23,51)$.

\section{Neutrophils}

Neutrophils are the third member of the innate immune cell repertoire to play a vital role in skin cancer $(52,53)$. The full extent of neutrophil functions in skin cancers is yet to be revealed as several studies suggested that like macrophages, neutrophils can be tumor-promoting or anti-tumor $(13,15)$. Neutrophils migrate into melanoma using the CXCR2 chemokine receptor in response to its ligands CXCL1, CXCL2, and CXCL5 expressed in melanoma (7). CXCL5 was upregulated in human stage T4 melanoma biopsies, which correlated with greater neutrophil infiltration and locoregional metastasis, when compared to stage T1 human melanomas (34). Furthermore, in a metastatic murine xenograft model, overexpression of CXCL5 in human melanoma cells elicited increased neutrophil recruitment and neutrophil dependent tumor cell migration into lymphatic vessels leading to lymph node metastasis (34).

Melanoma grown in mice lacking CXCR2 display reduced inflammation, neutrophil recruitment and tumor growth (54). Notably IFN- $\beta$ knockout mice had increased CXCL1 and CXCL2 expression, suggesting that IFN- $\beta$ is likely to be an intrinsic regulator of neutrophil infiltration $(7,55)$. In another model of melanoma, CXCL6 was shown to be important for neutrophil infiltration into tumor. Moreover, anti-CXCL6 monoclonal antibodies reduced neutrophil recruitment, which had an effect of inhibiting melanoma growth (56).

\section{NK Cells}

NK cells are innate lymphocytes with a crucial role in anti-viral and tumor defense (57-59). Their homing to melanomas, where they mediated growth regression, was dependent on CXCR3 as CXCR3-deficient NK cells failed to migrate into melanoma (60). Furthermore, higher levels of CCL5 in melanoma increased NK cell infiltration, reduced tumor size and could be used as a predictor for patient survival (28).

\section{CHEMOKINE-DRIVEN EFFECTOR T CELL RECRUITMENT IN SKIN CANCER}

$\mathrm{T}$ cells have crucial roles to play in controlling certain infections and cancers including those located in the skin. 
TABLE 1 | Chemokines implicated in regulating immune responses in melanoma.

\begin{tabular}{|c|c|c|c|c|}
\hline Chemokines & Cellular sources & Regulation & Effect on innate immunity & Effect on adaptive immunity \\
\hline CCL2 & $\begin{array}{l}\text { Stromal/Immune cells (21) } \\
\text { Melanoma (22) }\end{array}$ & $\begin{array}{l}\text { Activation } \\
\text { TNF (23) }\end{array}$ & $\begin{array}{l}\text { Low levels of CCL2: recruitment } \\
\text { of macrophages and enhanced } \\
\text { angiogenesis and tumor } \\
\text { formation (23) } \\
\text { High levels of CCL2: infiltration of } \\
\text { anti-tumor macrophages leading } \\
\text { to tumor regression (23) }\end{array}$ & $\begin{array}{l}\text { Expression correlated with increased } \\
\text { tumor CD3+, CD8+ T cell infiltration } \\
(6,24,25) \text {, improved response to } \\
\text { checkpoint inhibitors (25) and survival (24) } \\
\text { Lack of CCL2 or CCR2 reduced } \gamma \delta \text { T cell } \\
\text { infiltration and increased tumor growth (26) }\end{array}$ \\
\hline CCL20 & Tumor macrophages (30) & $\begin{array}{l}\text { Activation } \\
\text { TNF (30) }\end{array}$ & $\begin{array}{l}\text { DC recruitment into melanoma } \\
\text { and T cell-dependent inhibition } \\
\text { of tumor growth (31) }\end{array}$ & \\
\hline CCL21 & $\begin{array}{l}\text { Melanoma cell lines } \\
\text { MDA-MB-435S (32) and B16F10 } \\
\text { (9) }\end{array}$ & & & $\begin{array}{l}\text { Increased Treg infiltration and tumor } \\
\text { growth (9) }\end{array}$ \\
\hline CCL22 & Melanoma cell line B16F10 (33) & & & $\begin{array}{l}\text { Overexpression of CCL22 in skin diverted } \\
\text { Treg cells from lung metastasis leading to } \\
\text { inhibition of metastatic growth in the lung } \\
\text { (33) }\end{array}$ \\
\hline CXCL1,2,5 & Tumor neutrophils (7) & $\begin{array}{l}\text { Inhibition } \\
\text { IFN- } \beta \text { (7) }\end{array}$ & $\begin{array}{l}\text { Neutrophil recruitment into } \\
\text { melanoma leading to } \\
\text { angiogenesis and tumor growth } \\
\text { (7). CXCL5 promoted neutrophil } \\
\text { dependent tumor cell migration } \\
\text { into lymphatic vessels (34). }\end{array}$ & \\
\hline CXCL12 & $\begin{array}{l}\text { Tumor macrophage (41) } \\
\text { Tumor endothelium (42) }\end{array}$ & & $\begin{array}{l}\text { DC recruitment into melanoma, } \\
\text { CD8+ T cell dependent tumor } \\
\text { growth reduction (43) }\end{array}$ & $\begin{array}{l}\text { CXCL12 recruited CTLs into melanoma } \\
\text { (44) }\end{array}$ \\
\hline
\end{tabular}

The presence of CD8+ T cells in melanomas (61-63) as well as in other cancers (64-66) is associated with better clinical outcomes. Furthermore, patients with advanced melanomas have benefited from therapies designed to increase $\mathrm{T}$ cell infiltration of tumors including checkpoint inhibitors, $\mathrm{T}$ cell modulating cytokines (IL-2, IFN- $\gamma$ ) and adoptive T cell transfer. Therefore, a thorough understanding of chemokine-mediated $\mathrm{T}$ cell trafficking in skin cancer (Table 1) is crucial for achieving better treatment outcomes.

One of the earliest studies to link chemokine expression in human melanoma to $\mathrm{CD} 8+\mathrm{T}$ cell infiltration used gene expression arrays to identify CCL2-5 and CXCL9 as preferentially expressed in T cell rich patients' tumors $(6,29)$. Their corresponding chemokine receptors were upregulated on effector compared to naïve CD8+ $\mathrm{T}$ cells from normal controls (6). In another study higher expression of CCL3-5 and CXCL9-11 in human melanoma tissue was associated with increased CD8 $+\mathrm{T}$ cell recruitment and patient survival $(24,67)$. Furthermore, analysis of chemokines in melanoma prior to treatment identified CCL2 and CXCL9-12 as elevated in responding patients compared to non-responding patients (25). Tumor samples from patients with better clinical 
responses also had higher $\mathrm{T}$ cell counts around the invasive margins (25).

Expression of CCR5 and CXCR3 (receptors for CCL3-5 and CXCL9-11, respectively) on CD8 $+\mathrm{T}$ cells has emerged as another important regulator of effector $\mathrm{T}$ cell recruitment and prognosis in melanoma. For instance, higher expression of CCR5 and CXCR3 was associated with increased T cell infiltration of tumors, lower relapse rates (38) and increased survival in patients with advanced stage III disease (68). In mice CXCR3 deficiency led to faster growth of B16 melanoma (69), while loss of CXCR3 on circulating T cells from patients with melanoma was associated with metastases (70). Notably, CXCR3 signaling appears to be non-redundant and critical for $\mathrm{CD} 8+\mathrm{T}$ cell trafficking across the endothelium of blood vessels supplying both B16 melanomas and melanoma xenografts (46). Therefore, modulating the CCR5/CCL3-5 and CXCR3/CXCL911 chemokine axes can potentially improve $\mathrm{CD} 8+\mathrm{T}$ cell infiltration of tumors. However, Tregs also express the same receptors and may suppress cytotoxic $\mathrm{T}$ cell function.

The role of other chemokines involved in $\mathrm{T}$ cell migration into melanoma is less well defined. On the one hand, CXCL12 has been detected in normal and neoplastic tissue (71) and loss of T cells expressing its receptor, CXCR4, was linked to development of lung metastases (70). On the other hand, cytotoxic T cells expressing CXCR4 could migrate into melanoma in response to low concentrations of CXCL12 whereas a high concentration of this chemokine caused $\mathrm{T}$ cells to undergo fugetaxis $(44,71-$ 73), highlighting a complex concentration-dependent role for CXCL12 at least in this form of skin cancer.

CCL5 expression in a murine model of spontaneous melanoma correlated with $\mathrm{CD} 3 \gamma$ expression and $\mathrm{T}$ cell recruitment, while increased level of CCR5, the receptor for CCL5, was associated with positive outcomes in melanoma models due to $\mathrm{T}$ cell retention in tumors (29). Furthermore, the naturally occurring CCR $5 \Delta 32$ polymorphism appears to be linked to decreased survival in response to administration of IFN, IL-2, and/or chemotherapy (74). In contrast to these findings, pre-treatment assessment of tumor-infiltrating lymphocytes in patients receiving adoptive $\mathrm{T}$ cell therapy showed that patients with the CCR5 $\triangle 32$ polymorphism displayed an improved response to that therapy (38).

While CD8+ T cell infiltration of solid tumors is generally associated with improved outcomes, other $\mathrm{T}$ cell subsets can play dual roles in tumor immunity. For instance, $\gamma \delta \mathrm{T}$ cells possess both cytotoxic and tumor protective properties $(75,76)$. CCL2/CCR2 receptor ligand pair has been implicated in $\gamma \delta$ $\mathrm{T}$ cell recruitment in B16 melanoma where they may exert a cytotoxic effect mediated by IFN- $\gamma$, perforin and granzyme B (26). Mycobacterium bovis bacillus Calmette-Guérin injection in melanoma patients increased recruitment of $\gamma \delta \mathrm{T}$ cells via CXCL9-11 and CXCR3 (40). Despite this and evidence that $\gamma \delta \mathrm{T}$ cells are capable of lysing melanoma cells (77), other studies have shown a negative association of increased $\gamma \delta \mathrm{T}$ cells in circulation in melanoma patients with survival (78). $\gamma \delta$ T cells in patients' cutaneous SCC expressed CXCR2-4, CCR2-5, while ligands for these receptors were expressed in cultured SCC supporting a role for these chemokines in $\gamma \delta \mathrm{T}$ cell recruitment (79).
Another largely overlooked aspect of $\mathrm{T}$ cell recruitment is that tumor infiltration is not necessarily a "one-way trip." Our group has recently demonstrated that effector $\mathrm{T}$ cells recruited to solid tumors in the skin can also leave tumors and migrate to tumor draining lymph nodes (80). Thus, the extent of their egress vs. retention may influence the magnitude and nature of the antitumor response. Although little is known about the molecular mechanisms guiding these processes, it is likely that chemokines play an important contributory role.

\section{SYSTEMIC THERAPY AND IMMUNE CELL INFILTRATION}

Systemic therapy can influence the composition of the tumor microenvironment. For instance, chemotherapy causes tumor cell apoptosis, which can in turn induce chemoattractant stress signals. Moreover, therapies such as dacarbazine and temozolomide induce the $\mathrm{CD} 8+\mathrm{T}$ cell chemoattractants CCL5, CXCL9, and CXCL10 in human melanoma cell lines (29). Consistent with this finding, transcriptomic analysis of 33 cutaneous melanoma metastases resected before or after dacarbazine treatment showed a positive correlation between CCL5, CXCL9 and CXCL10 and CD4, CD8A and CD3Z expression. Thus, patients with high expression of these chemokines after chemotherapy survived longer possibly due to increased T cell recruitment (29). Furthermore, IFN$\gamma$ treatment induced chemokines CXCL9 and CXCL10 in melanoma potentially facilitating $\mathrm{T}$ cell infiltration (36). Tumors that developed resistance to IFN- $\gamma$ ceased CXCL9 production and became more tumorigenic (81). Notably, gene expression sequences from melanoma biopsies also revealed a positive correlation between CCL5, CXCL2, CXCL9, and CXCL10 and clinical benefit in a phase II trial of a MAGE-A3 vaccine (39).

Inhibitors of MAPK signaling, such as BRAF and MEK inhibitors, are used to treat BRAF mutated melanoma (82) and can alter the melanoma immune landscape leading to increased $\mathrm{T}$ cell infiltration (83-87). When combined with checkpoint inhibitors, BRAF inhibitors enhanced anti-tumor response and improved overall survival (83). These effects may be mediated by altering chemokine-induced immune migration into tumors since BRAF inhibition in melanoma increased serum levels of CCL2, CCL4, and decreased CXCL8 (86), which correlated with increased $\mathrm{CD} 8+\mathrm{T}$ cell infiltration.

Checkpoint inhibitor therapy in melanoma represents another example where modulation of the chemokine tumor microenvironment occurs as a result of anti-cancer intervention. Administration of anti-PD-1 antibody enhanced migration of the adoptively transferred $\mathrm{T}$ cells into B16 melanoma followed by greater tumor regression (88). The tumors had higher expression of IFN- $\gamma$ and CXCL10 while IFN- $\gamma \mathrm{R}^{-/-}$mice and $\mathrm{CXCL}_{10}{ }^{-/-}$mice showed reduced $\mathrm{T}$ cell infiltration. Immunochemical analysis of primary tumor biopsies from patients demonstrated a relationship between higher type 1 IFN expression and higher intratumoral CXCL10 as well as increased numbers of $\mathrm{CXCR}^{+}$and granzyme $\mathrm{B}^{+}$lymphocytes 
(89). Furthermore, analysis of gene expression profiles of biopsies collected from 45 melanoma patients before and after commencing anti-CTLA4 (ipilimumab) therapy, showed that in patients with clinical responses to ipilimumab there was increased expression pre- and post-treatment of CXCL911, CCL4 and CCL5, chemokines associated with $\mathrm{T}$ cell trafficking into melanoma (27). However, some of the above chemokines affect not only $\mathrm{T}$ cell recruitment but also innate immune cells.

Recent studies have demonstrated the immense potential of transcriptomics and single-cell RNA-sequencing (RNA-seq) in uncovering chemokine-mediated cellular interactions in melanoma and mechanisms of resistance to immunotherapy (90-93). For instance, transcriptomic studies have identified a checkpoint inhibitor resistance signature, which included monocyte and macrophage chemotactic genes (CCL2, CCL7, CCL8, and CCL13) (90). A recent study uncovered a tumor resistance program that was associated with $\mathrm{T}$ cell exclusion and immune evasion, predicted clinical response to checkpoint therapy in melanoma patients. This program could be repressed by cyclin dependent kinase (CDK) 4/6 inhibition suggesting new strategies to negate immunotherapy resistance (91).

\section{IMMUNE EVASION BY CHEMOKINE AUGMENTATION}

Immune evasion by skin cancers like melanoma represents one of the mechanisms whereby they proliferate and metastasize (94). Immunosuppressive cells of the innate (discussed above) and adaptive immune systems are recruited to the tumor microenvironment by a range of chemokines. In the case of immunogenic tumors like melanoma, Tregs have the potential to dampen the tumor-specific $\mathrm{T}$ cell response. Cutaneous overexpression of CCL22 led to diversion of Tregs from pulmonary melanoma metastases to the skin, leading to inhibition of metastatic growth in the lungs (33). Other studies have shown CCR5-dependent recruitment of Tregs into melanoma and $\operatorname{SCC}(8,95)$, while the ligands for this receptor were produced by MDSCs (8). Consistent with this, CCR5-deficient mice demonstrated slower rate of melanoma growth $(8,95)$. In another study, B16 melanoma cells overexpressing CCL21 displayed increased growth potential and on injection induced a more suppressive tumor environment containing increased Tregs and TGF $\beta$ but decreased IFN- $\gamma$ levels (9). However, not all retrospective studies of clinical melanoma samples supported the importance of Tregs in modulating anti-tumor responses, indicating the need for more research.

Blocking infiltration of cytotoxic effector cells into tumors is another possible mechanism of evasion and may be one of the reasons why checkpoint inhibitors are not always effective for melanoma treatment (96). Evidence for $\mathrm{T}$ cell blockade comes from analysis of a metastatic model of B16 melanoma. In this model, CD8+ $\mathrm{T}$ cell infiltration was dependent on the two CXCR3-cognate ligands, CXCL9 and CXCL10, but once metastatic spread had occurred both chemokines were decreased in metastatic lesions $(37,97)$. Furthermore, CXCL9 and CXCL10 expression in primary melanoma samples from patients was associated with greater $\mathrm{CD} 8+\mathrm{T}$ cell infiltration whereas biopsies taken from metastatic lesions were lower (97). CXCL9 and CXCL10 expression was decreased by adenosine signaling as metastatic melanoma developed in the lungs indicative of the ability of the tumor to suppress the chemokines responsible for attracting the CD8+ $\mathrm{T}$ cells (37). Notably, adoptively transferred CXCR3+ tumor-specific CD8+ $\mathrm{T}$ cells were capable of infiltrating metastatic tumors in the lungs (37).

\section{CONCLUDING REMARKS}

The clinical importance of chemokine-dependent immune cell recruitment into tumors is illustrated by the most recent advances in cancer immunotherapy, in particular checkpoint inhibitor therapy $(88,98)$, which has been very effective in about a third of patients with melanoma while the remainder have not responded. It is possible that differential chemokine expression may partially explain this all-or-none effect. Manipulating chemokine levels in primary tumors offers the opportunity for selective control of immune cell recruitment into tumors, thereby increasing the therapeutic efficacy of immunotherapy. However, many variables currently prevent the targeting of chemokines from becoming a realistic therapeutic approach. For example, chemokines play a complex multifunctional role in tumor development, growth and metastasis and their effect can be either pro-tumor or antitumor. Cells of the innate and adaptive immune systems with opposing functions in tumor immunity can respond to the same chemokines and be recruited into the tumor. Thus, optimization of immunotherapy will depend on further studies of the chemokine receptor-ligand pairs operating in the tumor microenvironment-likewise for anti-cancer vaccines the efficacy of which relies on recruitment of antigen-specific $\mathrm{T}$ cells to tumors.

\section{AUTHOR CONTRIBUTIONS}

All authors listed have made a substantial, direct and intellectual contribution to the work, and approved it for publication.

\section{FUNDING}

This research was funded by the National Health and Medical Research Council project grant GNT1106043 (TC), Australian Government Research Training Program Scholarship (AOY), Royal Australasian College of Physicians Fellows Research Entry Scholarship (AOY) and Phil Salter Fellowship (AOY).

\section{ACKNOWLEDGMENTS}

We thank Prof. Anthony Basten for critical reading of the manuscript. 


\section{REFERENCES}

1. Gunn MD, Kyuwa S, Tam C, Kakiuchi T, Matsuzawa A, Williams LT, et al. Mice lacking expression of secondary lymphoid organ chemokine have defects in lymphocyte homing and dendritic cell localization. J Exp Med. (1999) 189:451-60. doi: $10.1084 /$ jem.189.3.451

2. Bar-Eli M. Role of interleukin-8 in tumor growth and metastasis of human melanoma. Pathobiology. (1999) 67:12-8. doi: 10.1159/ 000028045

3. Jaramillo M, Godbout M, Naccache PH, Olivier M. Signaling events involved in macrophage chemokine expression in response to monosodium urate crystals. J Biol Chem. (2004) 279:52797-805. doi: 10.1074/jbc. M403823200

4. Yao L, Lowy FD, Berman JW. Interleukin-8 gene expression in Staphylococcus aureus-infected endothelial cells. Infect Immun. (1996) 64:3407-9.

5. Bottcher JP, Bonavita E, Chakravarty P, Blees H, Cabeza-Cabrerizo M, Sammicheli S, et al. NK cells stimulate recruitment of $\mathrm{CDC1}$ into the tumor microenvironment promoting cancer immune control. Cell. (2018) 172:102237 e14. doi: 10.1016/j.cell.2018.01.004

6. Harlin H, Meng Y, Peterson AC, Zha Y, Tretiakova M, Slingluff $\mathrm{C}$, et al. Chemokine expression in melanoma metastases associated with CD8+ T-cell recruitment. Cancer Res. (2009) 69:3077-85. doi: 10.1158/0008-5472.CAN-08-2281

7. Jablonska J, Wu CF, Andzinski L, Leschner S, Weiss S. CXCR2-mediated tumor-associated neutrophil recruitment is regulated by IFN-beta. Int $J$ Cancer. (2014) 134:1346-58. doi: 10.1002/ijc.28551

8. Schlecker E, Stojanovic A, Eisen C, Quack C, Falk CS, Umansky V, et al. Tumor-infiltrating monocytic myeloid-derived suppressor cells mediate CCR5-dependent recruitment of regulatory T cells favoring tumor growth. $J$ Immunol. (2012) 189:5602-11. doi: 10.4049/jimmunol.1201018

9. Shields JD, Kourtis IC, Tomei AA, Roberts JM, Swartz MA. Induction of lymphoidlike stroma and immune escape by tumors that express the chemokine CCL21. Science. (2010) 328:749-52. doi: 10.1126/science.1185837

10. Spranger S, Bao R, Gajewski TF. Melanoma-intrinsic beta-catenin signalling prevents anti-tumour immunity. Nature. (2015) 523:231-5. doi: 10.1038/nature14404

11. Fridman WH, Pages F, Sautes-Fridman C, Galon J. The immune contexture in human tumours: impact on clinical outcome. Nat Rev Cancer. (2012) 12:298-306. doi: $10.1038 / \mathrm{nrc} 3245$

12. Spranger S, Spaapen RM, Zha Y, Williams J, Meng Y, Ha TT, et al. Up-regulation of PD-L1, IDO, and T(regs) in the melanoma tumor microenvironment is driven by CD8+T cells. Sci Transl Med. (2013) 5:200ra116. doi: 10.1126/scitranslmed.3006504

13. Fridlender ZG, Sun J, Kim S, Kapoor V, Cheng G, Ling L, et al. Polarization of tumor-associated neutrophil phenotype by TGF-beta: "N1" versus "N2" TAN. Cancer Cell. (2009) 16:183-94. doi: 10.1016/j.ccr.2009.06.017

14. Mantovani A, Sozzani S, Locati M, Allavena P, Sica A. Macrophage polarization: tumor-associated macrophages as a paradigm for polarized M2 mononuclear phagocytes. Trends Immunol. (2002) 23:549-55. doi: 10.1016/S1471-4906(02)02302-5

15. Sagiv JY, Voels S, Granot Z. Isolation and characterization of low- vs. highdensity neutrophils in cancer. In: Ursini-Siegel J, Beauchemin N, editors. The Tumor Microenvironment: Methods and Protocols. New York, NY: Springer New York (2016).

16. Caunt M, Hu L, Tang T, Brooks PC, Ibrahim S, Karpatkin S. Growth-regulated oncogene is pivotal in thrombin-induced angiogenesis. Cancer Res. (2006) 66:4125-32. doi: 10.1158/0008-5472.can-05-2570

17. Murakami T, Maki W, Cardones AR, Fang H, Tun Kyi A, Nestle FO, et al. Expression of CXC chemokine receptor- 4 enhances the pulmonary metastatic potential of murine B16 melanoma cells. Cancer Res. (2002) 62:732834. Available online at: http://cancerres.aacrjournals.org/content/62/24/7328. long

18. Chow MT, Luster AD. Chemokines in cancer. Cancer Immunol Res. (2014) 2:1125-31. doi: 10.1158/2326-6066.CIR-14-0160

19. Jacquelot N, Duong CPM, Belz GT, Zitvogel L. Targeting chemokines and chemokine receptors in melanoma and other cancers. Front Immunol. (2018) 9:2480. doi: 10.3389/fimmu.2018.02480
20. Nagarsheth N, Wicha MS, Zou W. Chemokines in the cancer microenvironment and their relevance in cancer immunotherapy. Nat Rev Immunol. (2017) 17:559-72. doi: 10.1038/nri.2017.49

21. Redon CE, Dickey JS, Nakamura AJ, Kareva IG, Naf D, Nowsheen S, et al. Tumors induce complex DNA damage in distant proliferative tissues in vivo. Proc Natl Acad Sci USA. (2010) 107:17992-7. doi: 10.1073/pnas.1008260107

22. Graves DT, Barnhill R, Galanopoulos T, Antoniades HN. Expression of monocyte chemotactic protein-1 in human melanoma in vivo. Am J Pathol. (1992) 140:9-14.

23. Nesbit M, Schaider H, Miller TH, Herlyn M. Low-level monocyte chemoattractant protein-1 stimulation of monocytes leads to tumor formation in nontumorigenic melanoma cells. J Immunol. (2001) 166:6483-90. doi: 10.4049/jimmunol.166.11.6483

24. Messina JL, Fenstermacher DA, Eschrich S, Qu X, Berglund AE, Lloyd MC, et al. 12-Chemokine gene signature identifies lymph node-like structures in melanoma: potential for patient selection for immunotherapy? Sci Rep. (2012) 2:765. doi: $10.1038 /$ srep00765

25. Shields BD, Mahmoud F, Taylor EM, Byrum SD, Sengupta D, Koss B, et al. Indicators of responsiveness to immune checkpoint inhibitors. Sci Rep. (2017) 7:807. doi: 10.1038/s41598-017-01000-2

26. Lanca T, Costa MF, Goncalves-Sousa N, Rei M, Grosso AR, Penido C, et al. Protective role of the inflammatory CCR2/CCL2 chemokine pathway through recruitment of type 1 cytotoxic gammadelta T lymphocytes to tumor beds. $J$ Immunol. (2013) 190:6673-80. doi: 10.4049/jimmunol.1300434

27. Ji RR, Chasalow SD, Wang L, Hamid O, Schmidt H, Cogswell J, et al. An immune-active tumor microenvironment favors clinical response to ipilimumab. Cancer Immunol Immunother. (2012) 61:1019-31. doi: 10.1007/s00262-011-1172-6

28. Mgrditchian T, Arakelian T, Paggetti J, Noman MZ, Viry E, Moussay E,et al. Targeting autophagy inhibits melanoma growth by enhancing NK cells infiltration in a CCL5-dependent manner. Proc Natl Acad Sci USA. (2017) 114:E9271-e9279. doi: 10.1073/pnas.1703921114

29. Hong M, Puaux AL, Huang C, Loumagne L, Tow C, Mackay C, et al. Chemotherapy induces intratumoral expression of chemokines in cutaneous melanoma, favoring T cell infiltration and tumor control. Cancer Res. (2011) 71:6997-7009. doi: 10.1158/0008-5472.CAN-11-1466

30. Samaniego R, Gutierrez-Gonzalez A, Gutierrez-Seijo A, Sanchez-Gregorio S, Garcia-Gimenez J, Mercader E, et al. CCL20 expression by tumor-associated macrophages predicts progression of human primary cutaneous melanoma. Cancer Immunol Res. (2018) 6:267-275. doi: 10.1158/2326-6066.CIR-17-0198

31. Fushimi T, Kojima A, Moore MA, Crystal RG. Macrophage inflammatory protein 3alpha transgene attracts dendritic cells to established murine tumors and suppresses tumor growth. J Clin Invest. (2000) 105:1383-93. doi: 10.1172/JCI7548

32. Shields JD, Fleury ME, Yong C, Tomei AA, Randolph GJ, Swartz MA. Autologous chemotaxis as a mechanism of tumor cell homing to lymphatics via interstitial flow and autocrine CCR7 signaling. Cancer Cell. (2007) 11:52638. doi: $10.1016 /$ j.ccr.2007.04.020

33. Klarquist J, Tobin K, Farhangi Oskuei P, Henning SW, Fernandez MF, Dellacecca ER, et al. Ccl22 diverts $\mathrm{T}$ regulatory cells and controls the growth of melanoma. Cancer Res. (2016) 76:6230-40. doi: 10.1158/0008-5472.CAN-16-0618

34. Soler-Cardona A, Forsthuber A, Lipp K, Ebersberger S, Heinz M, Schossleitner K, et al. CXCL5 facilitates melanoma cell-neutrophil interaction and lymph node metastasis. J Invest Dermatol. (2018) 138:1627-35. doi: 10.1016/j.jid.2018.01.035

35. Amatschek S, Lucas R, Eger A, Pflueger M, Hundsberger H, Knoll C, et al. CXCL9 induces chemotaxis, chemorepulsion and endothelial barrier disruption through CXCR3-mediated activation of melanoma cells. $\mathrm{Br} \mathrm{J}$ Cancer. (2011) 104:469-79. doi: 10.1038/sj.bjc.6606056

36. Dengel LT, Norrod AG, Gregory BL, Clancy-Thompson E, Burdick $\mathrm{MD}$, Strieter RM, et al. Interferons induce CXCR3-cognate chemokine production by human metastatic melanoma. J Immunother. (2010) 33:965-74. doi: 10.1097/CJI.0b013e3181fb045d

37. Clancy-Thompson E, Perekslis TJ, Croteau W, Alexander MP, Chabanet $\mathrm{TB}$, Turk MJ, et al. Melanoma induces, and adenosine suppresses, CXCR3-cognate chemokine Production and T-cell Infiltration of lungs 
bearing metastatic-like disease. Cancer Immunol Res. (2015) 3:956-67. doi: 10.1158/2326-6066.CIR-15-0015

38. Bedognetti D, Spivey TL, Zhao Y, Uccellini L, Tomei S, Dudley ME, et al. CXCR3/CCR5 pathways in metastatic melanoma patients treated with adoptive therapy and interleukin-2. Br J Cancer. (2013) 109:2412-23. doi: 10.1038/bjc.2013.557

39. Ulloa-Montoya F, Louahed J, Dizier B, Gruselle O, Spiessens B, Lehmann FF, et al. Predictive gene signature in MAGE-A3 antigenspecific cancer immunotherapy. J Clin Oncol. (2013) 31:2388-95. doi: 10.1200/JCO.2012.44.3762

40. Yang J, Jones MS, Ramos RI, Chan AA, Lee AF, Foshag LJ, et al. Insights into local tumor microenvironment immune factors associated with regression of cutaneous melanoma metastases by Mycobacterium bovis bacille calmetteguerin. Front Oncol. (2017) 7:61. doi: 10.3389/fonc.2017.00061

41. Sanchez-Martin L, Estecha A, Samaniego R, Sanchez-Ramon S, Vega MA, Sanchez-Mateos P. The chemokine CXCL12 regulates monocytemacrophage differentiation and RUNX3 expression. Blood. (2011) 117:88-97. doi: 10.1182/blood-2009-12-258186

42. Maan ZN, Hu MS, Whittam A, Fischer LH, Duscher D, Walmsley GG, et al. Melanoma progression depends on CXCL12 expression by host endothelium. J Am Coll Surg. (2015) 221:S116. doi: 10.1016/j.jamcollsurg.2015.07.272

43. Fushimi T, O'Connor TP, Crystal RG. Adenoviral gene transfer of stromal cell-derived factor-1 to murine tumors induces the accumulation of dendritic cells and suppresses tumor growth. Cancer Res. (2006) 66:3513-22. doi: 10.1158/0008-5472.CAN-05-1493

44. Zhang T, Somasundaram R, Berking C, Caputo L, Van Belle P, Elder DE, et al. Preferential involvement of CX chemokine receptor 4 and CX chemokine ligand 12 in T-cell migration toward melanoma cells. Cancer Biol Ther. (2014) 5:1304-12. doi: 10.4161/cbt.5.10.3153

45. Roberts EW, Broz ML, Binnewies M, Headley MB, Nelson AE, Wolf DM, et al. Critical role for CD103(+)/CD141(+) dendritic cells bearing CCR7 for tumor antigen Trafficking and priming of T cell immunity in melanoma. Cancer Cell. (2016) 30:324-36. doi: 10.1016/j.ccell.2016.06.003

46. Mikucki ME, Fisher DT, Matsuzaki J, Skitzki JJ, Gaulin NB, Muhitch JB, et al. Non-redundant requirement for CXCR3 signalling during tumoricidal T-cell trafficking across tumour vascular checkpoints. Nat Commun. (2015) 6:7458. doi: $10.1038 /$ ncomms 8458

47. Spranger S, Dai D, Horton B, Gajewski TF. Tumor-residing batf3 dendritic cells are required for effector $\mathrm{T}$ cell trafficking and adoptive $\mathrm{T}$ cell therapy. Cancer Cell. (2017) 31:711-23 e4. doi: 10.1016/j.ccell.2017.04.003

48. Groom JR, Luster AD. CXCR3 in T cell function. Exp Cell Res. (2011) 317:620-31. doi: 10.1016/j.yexcr.2010.12.017

49. Barry KC, Hsu J, Broz ML, Cueto FJ, Binnewies M, Combes AJ, et al. A natural killer-dendritic cell axis defines checkpoint therapyresponsive tumor microenvironments. Nat Med. (2018) 24:1178-91. doi: 10.1038/s41591-018-0085-8

50. Mantovani A, Marchesi F, Malesci A, Laghi L, Allavena P. Tumour-associated macrophages as treatment targets in oncology. Nat Rev Clin Oncol. (2017) 14:399-416. doi: 10.1038/nrclinonc.2016.217

51. Gazzaniga S, Bravo AI, Guglielmotti A, van Rooijen N, Maschi F, Vecchi A, et al. Targeting tumor-associated macrophages and inhibition of MCP-1 reduce angiogenesis and tumor growth in a human melanoma xenograft. $J$ Invest Dermatol. (2007) 127:2031-41. doi: 10.1038/sj.jid.5700827

52. Coussens LM, Tinkle CL, Hanahan D, Werb Z. MMP-9 supplied by bone marrow- derived cells contributes to skin carcinogenesis. Cell. (2000) 103:48190. doi: 10.1016/S0092-8674(00)00139-2

53. Dissemond J, Weimann TK, Schneider LA, Schneeberger A, ScharffetterKochanek K, Goos M et al. Activated neutrophils exert antitumor activity against human melanoma cells, reactive oxygen species-induced mechanisms and their modulation by granulocyte-macrophage-colony-stimulating factor. J Invest Dermatol. (2003) 121:936-38. doi: 10.1046/j.1523-1747.2003.12475.x

54. Singh S, Varney M, Singh RK. Host CXCR2-dependent regulation of melanoma growth, angiogenesis, and experimental lung metastasis. Cancer Res. (2009) 69:411-5. doi: 10.1158/0008-5472.CAN-08-3378

55. Jablonska J, Leschner S, Westphal K, Lienenklaus S, Weiss S. Neutrophils responsive to endogenous IFN-beta regulate tumor angiogenesis and growth in a mouse tumor model. J Clin Invest. (2010) 120:1151-64. doi: $10.1172 /$ JCI37223
56. Verbeke H, Struyf S, Berghmans N, Van Coillie E, Opdenakker G, Uyttenhove $\mathrm{C}$, et al. Isotypic neutralizing antibodies against mouse GCP-2/CXCL6 inhibit melanoma growth and metastasis. Cancer Lett. (2011) 302:54-62. doi: $10.1016 /$ j.canlet.2010.12.013

57. Bukowski JF, Woda BA, Habu S, Okumura K, Welsh RM. Natural killer cell depletion enhances virus synthesis and virus-induced hepatitis in vivo. $J$ Immunol. (1983) 131:1531-8.

58. Herberman RB, Nunn ME, Holden HT, Lavrin DH. Natural cytotoxic reactivity of mouse lymphoid cells against syngeneic and allogeneic tumors. II. characterization of effector cells. Int J Cancer. (1975) 16:230-9. doi: 10.1002/ijc.2910160205

59. Kiessling R, Klein E, Pross H, Wigzell, H. "Natural" killer cells in the mouse. II. cytotoxic cells with specificity for mouse moloney leukemia cells. characteristics of the killer cell. Eur J Immunol. (1975) 5:117-21. doi: 10.1002/eji.1830050209

60. Wennerberg E, Kremer V, Childs R, Lundqvist A. CXCL10-induced migration of adoptively transferred human natural killer cells toward solid tumors causes regression of tumor growth in vivo. Cancer Immunol Immunother. (2015) 64:225-35. doi: 10.1007/s00262-014-1629-5

61. Ladanyi A, Somlai B, Gilde K, Fejos Z, Gaudi I, Timar J. T-cell activation marker expression on tumor-infiltrating lymphocytes as prognostic factor in cutaneous malignant melanoma. Clin Cancer Res. (2004) 10:521-30. doi: 10.1158/1078-0432.Ccr-1161-03

62. van Houdt IS, Sluijter BJ, Moesbergen LM, Vos WM, de Gruijl TD, Molenkamp BG, et al. Favorable outcome in clinically stage II melanoma patients is associated with the presence of activated tumor infiltrating $\mathrm{T}$ lymphocytes and preserved MHC class I antigen expression. Int J Cancer. (2008) 123:609-15. doi: 10.1002/ijc.23543

63. Piras F, Colombari R, Minerba L, Murtas D, Floris C, Maxia C, et al. The predictive value of $\mathrm{CD} 8, \mathrm{CD} 4, \mathrm{CD} 68$, and human leukocyte antigen-D-related cells in the prognosis of cutaneous malignant melanoma with vertical growth phase. Cancer. (2005) 104:1246-54. doi: 10.1002/ cncr.21283

64. Piersma SJ, Jordanova ES, van Poelgeest MIE, Kwappenberg KMC, van der Hulst JM, Drijfhout JW, et al. High number of intraepithelial CD8+tumorinfiltrating lymphocytes is associated with the absence of lymph node metastases in patients with large early-stage cervical cancer. Cancer Res. (2007) 67:354. doi: 10.1158/0008-5472.CAN-06-3388

65. Kim ST, Jeong H, Woo OH, Seo JH, Kim A, Lee ES, et al. Tumorinfiltrating lymphocytes, tumor characteristics, and recurrence in patients with early breast cancer. Am J Clin Oncol. (2013) 36:224-31. doi: 10.1097/COC.0b013e3182467d90

66. Galon J, Costes A, Sanchez-Cabo F, Kirilovsky A, Mlecnik B, LagorcePagès C, et al. Type, density, and location of immune cells within human colorectal tumors predict clinical outcome. Science. (2006) 313:1960. doi: $10.1126 /$ science. 1129139

67. Martinet L, Le Guellec S, Filleron T, Lamant L, Meyer N, Rochaix P, et al. High endothelial venules (HEVs) in human melanoma lesions: major gateways for tumor-infiltrating lymphocytes. Oncoimmunology. (2012) 1:82939. doi: 10.4161/onci.20492

68. Mullins IM, Slingluff CL, Lee JK, Garbee CF, Shu J, Anderson SG, et al. CXC chemokine receptor 3 expression by activated CD8 $+\mathrm{T}$ cells is associated with survival in melanoma patients with stage III disease. Cancer Res. (2004) 64:7697. doi: 10.1158/0008-5472.CAN-04-2059

69. Chheda ZS, Sharma RK, Jala VR, Luster AD, Haribabu B. Chemoattractant receptors BLT1 and CXCR3 regulate antitumor immunity by facilitating CD8+ T cell migration into tumors. J Immunol. (2016) 197:2016-26. doi: 10.4049/jimmunol.1502376

70. Jacquelot N, Enot DP, Flament C, Vimond N, Blattner C, Pitt JM, et al. Chemokine receptor patterns in lymphocytes mirror metastatic spreading in melanoma. J Clin Invest. (2016) 126:921-37. doi: 10.1172/JCI80071

71. Vianello F, Papeta N, Chen T, Kraft P, White N, Hart WK, et al Murine B16 melanomas expressing high levels of the chemokine stromalderived factor-1/CXCL12 induce tumor-specific $\mathrm{T}$ cell chemorepulsion and escape from immune control. J Immunol. (2006) 176:2902-14. doi: 10.4049/jimmunol.176.5.2902

72. Zhang T, Somasundaram R, Berencsi K, Caputo L, Rani P, Guerry D, et al. CXC chemokine ligand 12 (Stromal Cell-Derived Factor 1) And CXCR4-dependent 
migration of CTLs toward melanoma cells in organotypic culture. J Immunol. (2005) 174:5856-63. doi: 10.4049/jimmunol.174.9.5856

73. Oelkrug C, and Ramage JM, Enhancement of $\mathrm{T}$ cell recruitment and infiltration into tumours. Clin Exp Immunol. (2014) 178:1-8. doi: $10.1111 /$ cei.12382

74. Ugurel S, Schrama D, Keller G, Schadendorf D, Brocker EB, Houben R, et al. Impact of the CCR5 gene polymorphism on the survival of metastatic melanoma patients receiving immunotherapy. Cancer Immunol Immunother. (2008) 57:685-91. doi: 10.1007/s00262-007-0407-z

75. Fleming C, Morrissey S, Cai Y, Yan, J. Gammadelta T cells, unexpected regulators of cancer development and progression. Trends Cancer. (2017) 3:561-70. doi: 10.1016/j.trecan.2017.06.003

76. Silva-Santos B, Serre K, Norell H. Gammadelta T cells in cancer. Nat Rev Immunol. (2015) 15:683-91. doi: 10.1038/nri3904

77. Ebert LM, Meuter S, Moser B. Homing and function of human skin T cells and NK cells, relevance for tumor surveillance. J Immunol. (2006) 176:4331-6. doi: 10.4049/jimmunol.176.7.4331

78. Wistuba-Hamprecht K, Di Benedetto S, Schilling B, Sucker A, Schadendorf D, Garbe C, et al. Phenotypic characterization and prognostic impact of circulating gammadelta and alphabeta T-cells in metastatic malignant melanoma. Int J Cancer. (2016) 138:698-704. doi: 10.1002/ijc. 29818

79. Lo Presti E, Toia F, Oieni S, Buccheri S, Turdo A, Mangiapane LR, et al. Squamous cell tumors recruit gammadelta $\mathrm{T}$ cells producing either IL17 or IFNgamma depending on the tumor stage. Cancer Immunol Res. (2017) 5:397-407. doi: 10.1158/2326-6066.CIR16-0348

80. Torcellan T, Hampton HR, Bailey J, Tomura M, Brink R, Chtanova T. In vivo photolabeling of tumor-infiltrating cells reveals highly regulated egress of T-cell subsets from tumors. Proc Natl Acad Sci USA. (2017) 114:5677-5682. doi: 10.1073/pnas.1618446114

81. Petro M, Kish D, Guryanova OA, Ilyinskaya G, Kondratova A, Fairchild $\mathrm{RL}$, et al. Cutaneous tumors cease CXCL9/Mig production as a result of IFN-gamma-mediated immunoediting. J Immunol. (2013) 190:832-41. doi: 10.4049/jimmunol.1201906

82. Menzies AM, Long GV. Dabrafenib and trametinib, alone and in combination for BRAF-mutant metastatic melanoma. Clin Cancer Res. (2014) 20:2035-43. doi: 10.1158/1078-0432.ccr-13-2054

83. Cooper ZA, Juneja VR, Sage PT, Frederick DT, Piris A, Mitra D, et al. Response to BRAF inhibition in melanoma is enhanced when combined with immune checkpoint blockade. Cancer Immunol Res. (2014) 2:643-54. doi: 10.1158/2326-6066.CIR-13-0215

84. Hu-Lieskovan S, Mok S, Homet Moreno B, Tsoi J, Robert L, Goedert L, et al. Improved antitumor activity of immunotherapy with BRAF and MEK inhibitors in BRAF(V600E) melanoma. Sci Transl Med. (2015) 7:279ra41. doi: 10.1126/scitranslmed.aaa4691

85. Knight DA, Ngiow SF, Li M, Parmenter T, Mok S, Cass A, et al. Host immunity contributes to the anti-melanoma activity of BRAF inhibitors. J Clin Invest. (2013) 123:1371-81. doi: 10.1172/JCI66236

86. Wilmott JS, Haydu LE, Menzies AM, Lum T, Hyman J, Thompson JF, et al. Dynamics of chemokine, cytokine, and growth factor serum levels in BRAF-mutant melanoma patients during BRAF inhibitor treatment. J Immunol. (2014) 192:2505-13. doi: 10.4049/jimmunol. 1302616
87. Wilmott JS, Long GV, Howle JR, Haydu LE, Sharma RN, Thompson JF, et al. Selective BRAF inhibitors induce marked T-cell infiltration into human metastatic melanoma. Clin Cancer Res. (2012) 18:1386-94. doi: 10.1158/1078-0432.CCR-11-2479

88. Peng W, Liu C, Xu C, Lou Y, Chen J, Yang Y, et al. PD-1 blockade enhances T-cell migration to tumors by elevating IFN-gamma inducible chemokines. Cancer Res. (2012) 72:5209-18. doi: 10.1158/0008-5472.CAN-12-1187

89. Wenzel J, Bekisch B, Uerlich M, Haller O, Bieber T, Tuting T. Type I interferon-associated recruitment of cytotoxic lymphocytes: a common mechanism in regressive melanocytic lesions. Am J Clin Pathol. (2005) 124:3748. doi: 10.1309/4EJ9KL7CGDENVVLE

90. Hugo W, Zaretsky JM, Sun L, Song C, Moreno BH, Hu-Lieskovan S,et al. Genomic and transcriptomic features of response to anti-PD-1 therapy in metastatic melanoma. Cell. (2016) 165:35-44. doi: 10.1016/j.cell.2016.02.065

91. Jerby-Arnon L, Shah P, Cuoco MS, Rodman C, Su MJ, Melms JC, et al. A cancer cell program promotes $\mathrm{T}$ cell exclusion and resistance to checkpoint blockade. Cell. (2018) 175:984-97 e24. doi: 10.1016/j.cell.2018.09.006

92. Kumar MP, Du J, Lagoudas G, Jiao Y, Sawyer A, Drummond DC, et al. Analysis of single-cell RNA-Seq identifies cell-cell communication associated with tumor characteristics. Cell Rep. (2018) 25:1458-68 e4. doi: 10.1016/j.celrep.2018.10.047

93. Tirosh I, Izar B, Prakadan SM, Wadsworth MH, Treacy D, Trombetta JJ,et al. Dissecting the multicellular ecosystem of metastatic melanoma by single-cell RNA-seq. Science. (2016) 352:189-96. doi: 10.1126/science.aad0501

94. Hanahan D, Weinberg RA. Hallmarks of cancer: the next generation. Cell. (2011) 144:646-74. doi: 10.1016/j.cell.2011.02.013

95. de Oliveira CE, Gasparoto TH, Pinheiro CR, Amor NG, Nogueira MRS, Kaneno $R$, et al. CCR5-dependent homing of $t$ regulatory cells to the tumor microenvironment contributes to skin squamous cell carcinoma development. Mol Cancer Ther. (2017) 16:2871-80. doi: 10.1158/1535-7163.MCT-17-0341

96. Gide TN, Wilmott JS, Scolyer RA, Long GV. Primary and acquired resistance to immune checkpoint inhibitors in metastatic melanoma. Clin Cancer Res. (2018) 24:1260-70. doi: 10.1158/1078-0432.CCR-17-2267

97. Kunz M, Toksoy A, Goebeler M, Engelhardt E, Bröcker EB, Gillitzer R. Strong expression of the lymphoattractant C-X-C chemokine Mig is associated with heavy infiltration of $\mathrm{T}$ cells in human malignant melanoma. $J$ Pathol. (2000) 189:552-8. doi: 10.1002/(SICI)1096-9896(199912)189:4<552::AIDPATH469>3.0.CO;2-I

98. Kershaw MH, Wang G, Westwood JA, Pachynski RK, Tiffany HL, Marincola $\mathrm{FM}$, et al. Redirecting migration of T cells to chemokine secreted from tumors by genetic modification with CXCR2. Hum Gene Ther. (2002) 13:1971-80. doi: $10.1089 / 10430340260355374$

Conflict of Interest Statement: The authors declare that the research was conducted in the absence of any commercial or financial relationships that could be construed as a potential conflict of interest.

Copyright (๑) 2019 Yam and Chtanova. This is an open-access article distributed under the terms of the Creative Commons Attribution License (CC BY). The use, distribution or reproduction in other forums is permitted, provided the original author(s) and the copyright owner(s) are credited and that the original publication in this journal is cited, in accordance with accepted academic practice. No use, distribution or reproduction is permitted which does not comply with these terms. 